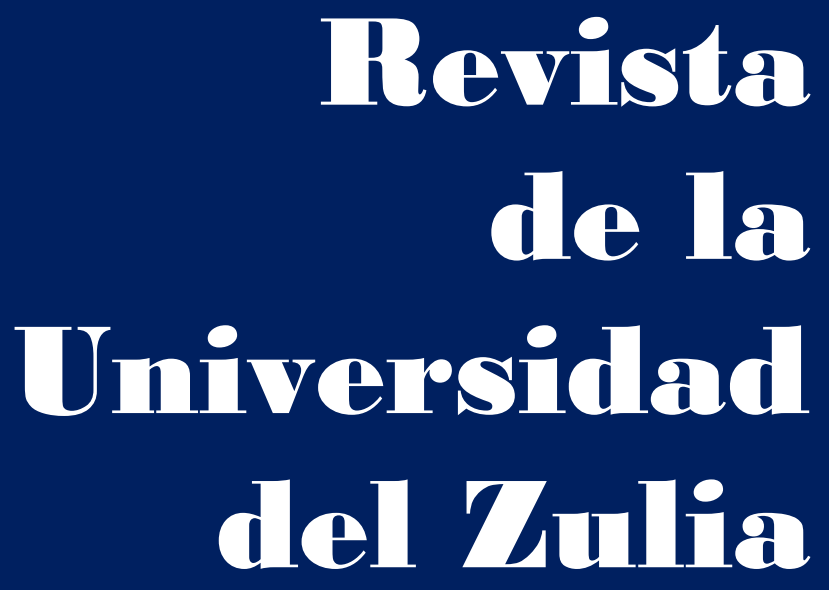

Fundada en 1947

por el Dr. Jesús Enrique Lossada



Ciencias del

Agred

Ingemieria

y Teenología
Añต 12 No 32

Enero - Abril 2021

Tercera Época

Maracailbo-Venezuela 


\title{
Efficiency of the use of perfluorocarbon gas transport drugs for various forms of anemia in animals
}

\author{
Sergej V. Votrin* \\ Sergej I. Vorobyev** \\ Sergey B. Bolevich*** \\ Aleksandra S. Orlova**** \\ Denis D. Gudanovich***
}

ABSTRACT

Purpose: The purpose of the article is to determine the effectiveness of the use of perfluorocarbon gas vehicles in acute, severe anemia in animals caused by external blood loss and autoimmune intravascular hemolysis. Methodology: The effectiveness of the use of perfluorocarbon gas transport agents in acute, severe anemia in animals caused by external blood loss and autoimmune intravascular hemolysis was carried out based on the assessment of lethality in groups, biochemical criteria that were determined using an automatic biochemical blood analyzer and an assessment of hematocrit, which was determined using an automatic an analyzer of a general clinical analysis of blood with an impedance counting system. Results: The high efficiency of the use of perfluorocarbon gas transport drug Perftoran in acute and severe anemia caused by external blood loss and autoimmune intravascular hemolysis was revealed on the basis of an assessment of the lethality of animals in groups in comparison with a blood preparation - donor erythrocyte mass. The lethality in the groups of animals that used the perfluorocarbon gas transport agent was significantly lower than that in the animals that used the erythrocyte mass, especially in acute and severe anemia caused by autoimmune intravascular hemolysis.

KEY WORDS: hypoxia, hemolysis, anemia, correction, erythrocyte mass, perfluorocarbon blood substitute, critical conditions

*Ph.D. student at the human pathology department Sechenov First Moscow State Medical Univesity (Sechenov Univesity) Moscow, Russia. ORCID: https:/orcid.org/0000-0003-1773-1662

**Doctor of Biological Sciences, Professor, the head of the human pathology department Sechenov First Moscow State Medical Univesity (Sechenov Univesity) Moscow, Russia. ORCID: https://orcid.org/00000003-1383-957X

***MD, Professor, the head of the human pathology department Sechenov First Moscow State Medical Univesity (Sechenov Univesity) Moscow, Russia. ORCID: https://orcid.org/0000-0002-1574-477X

**** $\mathrm{PhD}$ in Medicine, associate professor at the human pathology department Sechenov First Moscow State Medical University (Sechenov University) Moscow, Russia. ORCID: https://orcid.org/ 0000-0001-9725-7491

*****Ph.D. student Sklifosovsky Clinical and Research Institute for Emergency Medicine Moscow, Russia. ORCID: https://orcid.org/0000-0002-8014-1799

Recibido: 03/08/2020

Aceptado: 05/10/2020 
REVISTA DE LA UNIVERSIDAD DEL ZULIA. $3^{a}$ época. Año 12 N $^{\circ} 32,2021$

Sergej V. Votrin et al. // Efficiency of the use of perfluorocarbon gas transport... 24-34

DOI: http://dx.doi.org/10.46925//rdluz.32.03

\section{Eficiencia del uso de fármacos en el transporte de gas perfluorocarbonado para diversas formas de anemia en animales}

RESUMEN

Propósito: El propósito del artículo es determinar la efectividad del uso de vehículos de gas perfluorocarbonado en la anemia aguda y severa en animales causada por pérdida de sangre externa y hemólisis intravascular autoinmune. Metodología: La efectividad del uso de agentes transportadores de gas perfluorocarbonado en la anemia aguda severa en animales causada por hemorragia externa y hemólisis intravascular autoinmune, se llevó a cabo en base a la evaluación de la letalidad en grupos, criterios bioquímicos que se determinaron utilizando una sangre bioquímica automática, y una evaluación del hematocrito, que se determinó utilizando un analizador automático de análisis clínico general de sangre con un sistema de recuento de impedancia. Resultados: La alta eficiencia del uso del fármaco de transporte de gas perfluorocarbonado - Perftoran en la anemia aguda y grave causada por la pérdida de sangre externa y la hemólisis intravascular autoinmune se reveló sobre la base de una evaluación de la letalidad de los animales en grupos, en comparación con una preparación de sangre - masa de eritrocitos del donante. La letalidad en los grupos de animales que usaron el agente de transporte de gas perfluorocarbonado fue significativamente menor que en los animales que usaron la masa de eritrocitos, especialmente en la anemia aguda y severa causada por hemólisis intravascular autoinmune.

PALABRAS CLAVE: hipoxia, hemólisis, anemia, corrección, masa eritrocitaria, sustituto sanguíneo de perfluorocarbono, condiciones críticas

\section{Introduction}

The success of treatment in the complex therapy of any critical conditions in the animal clinic is determined by the rapid restoration of vital functions, as well as the prompt elimination of oxygen deficiency in various organs and systems of the body. From this point of view, the interest shown by researchers from different countries to the use of artificial gastransporting blood-substituting drugs for anemia of various genesis is understandable (Ragimov, 2015; Bialas et al., 2019; Spiess, 2019).

It is known that critical conditions arise both in acute posthemorrhagic anemia caused by massive external blood loss and in acute autoimmune hemolytic anemia caused by immune lysis of erythrocytes and can be accompanied by both intravascular and extravascular hemolysis (Shiffman, 2017). 
REVISTA DE LA UNIVERSIDAD DEL ZULIA. 3ª época. Año $12 \mathrm{~N}^{\circ} 32,2021$ Sergej V. Votrin et al. // Efficiency of the use of perfluorocarbon gas transport... 24-34 DOI: http://dx.doi.org/10.46925//rdluz.32.03

Replacement therapy for massive external blood loss should be carried out immediately to eliminate hypoxia in severe acute posthemorrhagic anemia. However, the issue of transfusions of blood and its components in the treatment of acute and severe blood loss is currently ambiguous. It is necessary to avoid unreasonable blood transfusions in an immune complex recipient (Ragimov, 2015; Vorobyev et al., 2020).

In acute autoimmune hemolytic anemia, the destruction of erythrocytes as a result of acute autoimmune intravascular hemolysis deserves special attention. Acute autoimmune intravascular hemolysis is a type of acute pathological hemolysis characterized by the destruction of erythrocytes in the vascular bed under the influence of antibodies and a compliment. This is a rapidly developing, autoimmune process, in which the compensatory forces of the body do not have time to turn on in full (Alekseev, 2004).

Acute autoimmune intravascular hemolysis underlies the pathogenesis of blood parasitic diseases. Intravascular hemolysis is especially pronounced in its pathological effect in complicated canine babesiosis. In this disease, erythrocytes are directly damaged by hemoparasites, and their decay products cause a severe acute autoimmune process, manifested in the form of intravascular hemolysis (Nimand and Suter, 2004).

With the rapid development of such pathological processes as acute posthemorrhagic anemia and acute autoimmune hemolytic anemia, the compensatory mechanisms of the body do not have time to develop sufficient power; accordingly, clinical manifestations, as a rule, end in a high mortality rate (Shiffman, 2017).

In this regard, the aim of this study is devoted to the correction of critical conditions (lethality) caused by acute posthemorrhagic anemia and acute autoimmune hemolytic anemia using a blood-substituting gas transport emulsion of perfluorocarbons of the Perftoran type (Russia) in comparison with the traditional erythrocyte mass.

\section{Materials and methods}

In the first block of retrospective studies in acute posthemorrhagic anemia, 41 cats of both sexes were selected, admitted to the Clinic of Veterinary Medicine of the Scientific Center for Biological Research in the city of Pushchino with bleeding as a result of various injuries in the period 2009-2018. Animals were randomized according to the method of treatment into 3 groups. 
REVISTA DE LA UNIVERSIDAD DEL ZULIA. 3ª época. Año $12 \mathrm{~N}^{\circ} 32,2021$

Sergej V. Votrin et al. // Efficiency of the use of perfluorocarbon gas transport... 24-34

DOI: http://dx.doi.org/10.46925//rdluz.32.03

The first control group $(\mathrm{n}=17)$ included animals for the treatment of which traditional infusion therapy was used, including the use of a colloidal solution "Stabizol" at a dose of 20 $\mathrm{ml} / \mathrm{kg}$ of body weight (Plumb, 2002).

The second group $(n=13)$ included animals for the treatment of which traditional infusion therapy was used on the first day of admission to the clinic, including the use of a colloidal solution "Stabizol" at a dose of $20 \mathrm{ml} / \mathrm{kg}$ body weight; these animals were transfused with donor $\mathrm{EO}$ at a dose of $10 \mathrm{ml} / \mathrm{kg}$ body weight one day after injury and bleeding (Vaden et al., 2013).

The third group $(\mathrm{n}=11)$ included animals for which, in addition to the colloidal solution "Stabizol", perfluorocarbon blood substitute "Perftoran" was used. The therapeutic dose was $10 \mathrm{ml} / \mathrm{kg}$ body weight, infusion was performed on the first, second, third, fifth, and seventh day after injury.

Animals with the same criteria were selected into three groups of the first block of studies: Ht 9-18\%, bilirubin 7-11 $\mu \mathrm{Mol} / \mathrm{L}$, lactate 2.3-5.4 m Mol / L, SpO $27-84 \%, \mathrm{~K}+4.1-5.4$ $\mathrm{mMol} / \mathrm{L}$. The creatinine level was within the normal range of 80-160 $\mu \mathrm{Mol} / \mathrm{L}$. Cats weighing 3-5 kg were selected.

In the second block of retrospective studies to correct hypoxia in acute autoimmune intravascular hemolysis, 79 dogs of both sexes were used, admitted to the Clinic of Veterinary Medicine of the Scientific Center for Biological Research in the city of Pushchino in the period 2009-2018 with a diagnosis of babesiosis complicated by acute autoimmune intravascular hemolysis.

In this experimental, retrospective, parallel-controlled study, animals were randomized into 3 treatment groups. Dogs with the same criteria were selected for all three groups: Ht 9-12\%, bilirubin 40-60 $\mu \mathrm{Mol} / \mathrm{L}$, lactate 5-6 m Mol / L, $\mathrm{SpO}_{2} 78-80 \%, \mathrm{~K}+3.6-5.6$ $\mathrm{mMol} / \mathrm{L}$. The creatinine level was within the reference values - 80-160 mMol / L.

The creatinine level was within the reference values - 80-160 $\mu \mathrm{Mol} / \mathrm{L}$. Dogs were selected whose weight ranged from 15 to $35 \mathrm{~kg}$. These dogs had plasma hemolysis, hemoglobinuria, anemicity and yellowness of the mucous membranes, microscopy of a blood smear revealed babesia and agglutination of erythrocytes (ER) in the form of coin bars, plasma was colored red during blood centrifugation, which confirmed the presence of acute autoimmune intravascular hemolysis as a result of infection of animals with babesiosis (Alekseev, 2004; Vaden et al., 2013). 
REVISTA DE LA UNIVERSIDAD DEL ZULIA. 3ª época. Año $12 \mathrm{~N}^{\circ} 32,2021$

Sergej V. Votrin et al. // Efficiency of the use of perfluorocarbon gas transport... 24-34 DOI: http://dx.doi.org/10.46925//rdluz.32.03

The first control group included 29 dogs for the treatment of which basic therapy was used, implying: prednisolone intravenously (IV) at a dose of $4 \mathrm{mg} / \mathrm{kg}$ once a day for five days in a row, which is used as an immunosuppressant, as a detoxification solution IV $\mathrm{NaCl} 0.9 \%-10 \mathrm{ml} / \mathrm{kg}$ was injected once a day for five consecutive days, antiprotozoal therapy was carried out by subcutaneous (sc) administration of Piro-Stop $0.5 \mathrm{ml} / 10 \mathrm{~kg}$ once. Pyro-Stop is an antiprotozoal drug from the imidazole group. As an active substance, $1 \mathrm{ml}$ of solution for injection contains $120 \mathrm{mg}$ of imidocarb dipropionate. Therapeutic dose for dogs is $0.5 \mathrm{ml}$ per $10 \mathrm{~kg}$ of animal weight, by subcutaneous administration, once (Plumb, 2002).

The second group included 28 animals, in which replacement therapy was carried out in addition to the basic one: to replenish the number of dead erythrocytes as a result of acute autoimmune intravascular hemolysis, on the first day of treatment, erythrocyte mass was used, with the help of which the recipient's hematocrit was raised to $20 \%$. To raise the recipient's $\mathrm{Ht}$ by $1 \%$, it takes $1 \mathrm{ml}$ of donor erythrocyte mass with $\mathrm{Ht}-45 \%$ per $\mathrm{kg}$ of the recipient's weight. The erythrocyte mass was used in a $0.9 \% \mathrm{NaCl}$ dilution in a l: 1 ratio; in general, the volume of a blood preparation with $\mathrm{Ht}-10 \%$ administered to the recipient was $20 \mathrm{ml} / \mathrm{kg}$ (Vaden et al., 2013; Nimand and Suter, 2004).

The third group included 22 dogs, which were added to the basic therapy with the introduction of the drug "Perftoran", at a dose of $10 \mathrm{ml} / \mathrm{kg}$ to reduce hypoxia resulting from acute autoimmune intravascular hemolysis, while the erythrocyte mass of these animals was not used.

The drug "Perftoran" is a submicron emulsion with an average size of "artificial erythrocytes" - $100 \mathrm{~nm}$ with gas transport functions, containing 20\% perfluorocarbons (PFCs): perfluorodecalin - $13 \mathrm{~g}$; perfluoromethylcyclohexylpiperidine - $6.5 \mathrm{~g}$; proxanol - $4 \mathrm{~g}$; sodium chloride - $0.6 \mathrm{~g}$; magnesium chloride - $0.019 \mathrm{~g}$; potassium chloride - $0.039 \mathrm{~g}$; sodium bicarbonate - $0.065 \mathrm{~g}$; glucose - $0.2 \mathrm{~g}$; sodium hydrogen phosphate - $0.02 \mathrm{~g}$; water for injection - up to $100 \mathrm{ml}$ (Vorobiev et al., 2016; Vorobyev et al., 2020).

The drug "Perftoran" was used as follows in the first experimental block of studies for the relief of hypoxia caused by acute posthemorrhagic anemia in cats: the drug was administered intravenously at a dose of $10 \mathrm{ml} / \mathrm{kg}$ once a day on days $1,2,3,5,7$ of treatment. 
REVISTA DE LA UNIVERSIDAD DEL ZULIA. 3ª época. Año 12 Nº 32, 2021 Sergej V. Votrin et al. // Efficiency of the use of perfluorocarbon gas transport... 24-34 DOI: http://dx.doi.org/10.46925//rdluz.32.03

In the second experimental block of studies for the relief of hypoxia caused by acute autoimmune intravascular hemolysis in dogs, the drug "Perftoran" was used intravenously at a dose of $10 \mathrm{ml} / \mathrm{kg}$ once a day for five consecutive days.

The introduction of the drug "Perftoran" in cats and dogs began with a bioassay, consisting in a gradual controlled introduction: $0.1 \mathrm{ml}$ of the drug diluted with $0.9 \% \mathrm{NaCl}$ to $5 \mathrm{ml}$, the drug was injected slowly intravenously, and then drip with pauses of 60 seconds $3,5,10,30$ drops, gradually increasing the infusion rate to one drop per second (Votrin et al., 2018; Votrin and Vorobiev, 2017).

According to the instructions for medical use of the drug "Perftoran", approved for clinical use in Russia since 1996 - perfluorocarbon blood substitute is a multifunctional drug with a wide spectrum of action (Ragimov, 2015).

2. Results and discussion

First block of research. As a result of a retrospective evaluation of the data on animals (cats) of the first block of studies with acute posthemorrhagic anemia, which were observed for 5 days, it was found that the lethality of animals in the groups differed significantly in the control group and in the two main groups, where hypoxia was corrected with the drug "Perftoran" and donor erythrocyte mass (table 1).

Table l. Mortality of animals (cats) during the correction of acute blood loss and posthemorrhagic anemia using the perfluorocarbon drug "Perftoran" and donor erythrocyte mass (EM) during 5 days of observation

\begin{tabular}{|c|c|c|c|c|c|c|}
\hline \multirow{2}{*}{ Groups } & \multirow{2}{*}{$\begin{array}{c}\text { Initial } \\
\text { number } \\
\text { of } \\
\text { animals }\end{array}$} & \multicolumn{4}{|c|}{ Observation time (days) } & \multirow{2}{*}{$\begin{array}{l}\text { General } \\
\text { mortality }\end{array}$} \\
\hline & & 1 & 2 & 3 & 5 & \\
\hline $\begin{array}{l}\text { lst group } \\
\text { The control }\end{array}$ & 17 & 3 & 2 & 2 & 1 & $\begin{array}{r}8 \text { from } 17 \\
(47,1 \%)\end{array}$ \\
\hline $\begin{array}{l}\text { 2nd group } \\
\text { Erythrocyte } \\
\text { mass }\end{array}$ & 13 & 2 & 1 & - & - & $\begin{array}{c}3 \text { from } 13 \\
(23,1 \%)\end{array}$ \\
\hline $\begin{array}{l}\text { Group } 3 \\
\text { "Perftoran" }\end{array}$ & 11 & 1 & - & - & - & $\begin{array}{c}1 \text { from ll } \\
(9,9 \%)\end{array}$ \\
\hline
\end{tabular}


REVISTA DE LA UNIVERSIDAD DEL ZULIA. 3ª época. Año $12 \mathrm{~N}^{\circ} 32,2021$

Sergej V. Votrin et al. // Efficiency of the use of perfluorocarbon gas transport... 24-34

DOI: http://dx.doi.org/10.46925//rdluz.32.03

The data obtained show that the highest mortality rate of $47.1 \%$ in cats is observed in the group without correction of hypoxia in the treatment of severe acute posthemorrhagic anemia. Mostly death was observed in the stage of vascular collapse and in the hydraemic stage, when hypoxia is most severe. It should be noted that in animals that used donor erythrocyte mass to correct hypoxia in acute posthemorrhagic anemia, the lethality was $23.1 \%$, which is two times lower than in the control and significantly higher (two or more times) than in the group. with an artificial blood substitute drug "Perftoran", where the mortality rate was $9.9 \%$. It is believed that donor erythrocytes are the best oxygen carriers, as they dissolve up to 21 vol.\% Oxygen (the drug "Perftoran" up to 7 vol.\%); however, in immunocomplex recipients, the decision on transfusion of donor erythrocyte mass is made on the basis of the hematocrit level, which, in case of external blood loss, is informative 18-20 hours after the lost plasma volume is restored (Ragimov, 2015). That is why on the first day in the group with erythrocyte mass there is a high mortality rate. In the group with the blood substitute "Perftoran", the lowest lethality was observed, which was due to the immediate use of an artificial oxygen carrier to the immune-complex recipient.

Certain changes in hematocrit, lactate, $\mathrm{SpO}_{2}$ were revealed on the basis of our previously obtained experimental data (Votrin and Vorobiev, 2017) on the correction of acute blood loss and posthemorrhagic anemia in animals using the perfluorocarbon gas transport drug "Perftoran" and donor erythrocyte mass. We believe that this directly affects the high mortality rate in the control and erythrocyte mass groups. It should be noted that the experimental group of animals with posthemorrhagic anemia resulting from blood loss, which received the drug "Perftoran" as part of the complex therapy, despite significant blood loss, had indicators: hematocrit, lactate, $\mathrm{SpO}_{2}$, characterizing a moderate level of hypoxia, significantly different from the indicators of animals the control group and the indices of the animals of the group after transfusion with donor erythrocyte mass (Votrin and Vorobiev, 2017).

Studies have shown that the infusion of the perfluorocarbon gas-transport drug "Perftoran", carried out by an injured animal in acute posthemorrhagic anemia to compensate for the hypoxic state, provides an oxygen reserve and allows the injured body, which has received serious damage, to stably endure anesthesia, surgery, which together reduces the mortality rate to 9 , nine $\%$. 
REVISTA DE LA UNIVERSIDAD DEL ZULIA. 3ㄹ época. Año $12 \mathrm{~N}^{\circ}$ 32, 2021 Sergej V. Votrin et al. // Efficiency of the use of perfluorocarbon gas transport... 24-34 DOI: http://dx.doi.org/10.46925//rdluz.32.03

Second block of research. As a result of a retrospective assessment of the data on animals (dogs) of the second block of studies with acute autoimmune hemolytic anemia, observed for 9 days, it was found that the mortality of animals in the groups differed significantly in the control group and in the two main groups, where hypoxia was corrected with the drug "Perftoran" and donor erythrocyte mass (table 2).

Table 2. Mortality of animals (dogs) during the correction of hypoxia caused by autoimmune intravascular hemolysis using the perfluorocarbon drug "Perftoran" and donor erythrocyte mass during 9 days of observation

\begin{tabular}{|c|c|c|c|c|c|c|c|c|c|}
\hline & \multirow{7}{*}{$\begin{array}{c}\text { Initial } \\
\text { Gumber of } \\
\text { animals }\end{array}$} & 1 & 3 & 5 & 6 & 7 & 8 & 9 & \multirow{2}{*}{$\begin{array}{c}\text { General } \\
\text { mortality }\end{array}$} \\
\cline { 5 - 9 } & 29 & 2 & 6 & 1 & - & 2 & 1 & 1 & $\begin{array}{c}13 \text { from } 29 \\
(41 \%)\end{array}$ \\
\hline $\begin{array}{c}\text { lst group } \\
\text { The control }\end{array}$ & 28 & 1 & 6 & 1 & 2 & - & 3 & 2 & $\begin{array}{c}15 \text { from } 28 \\
(53 \%)\end{array}$ \\
\hline $\begin{array}{c}\text { 2nd group } \\
\text { Erythrocyte } \\
\text { mass }\end{array}$ & 22 & 1 & - & 1 & 1 & - & - & - & $\begin{array}{c}3 \text { from } 22 \\
(13 \%)\end{array}$ \\
\hline $\begin{array}{c}\text { Group 3 } \\
\text { "Perftoran" }\end{array}$ & 22 & & &
\end{tabular}

Studies have shown that in the lst control group without hypoxia correction there is a high mortality rate as a result of increasing hypoxia up to $41 \%$; in the 2 nd group, the main one, where the animals used the erythrocyte mass for hypoxia correction, the highest lethality was observed up to 53\%; in the 3rd group, the main one, where "Perftoran" was used for hypoxia correction, the lethality was the lowest, no more than 13\% ( $<<0.05)$, 3.5-4 times lower than in the lst control group and 2nd group with erythrocyte mass (table 2).

Studies have shown that despite various methods of correcting hypoxia, a high mortality rate in animals occurs in anemia as a result of autoimmune hemolysis. Our early studies (Votrin et al., 2018) have shown that hyperbilirubinemia, hyperkalemia, acidosis, hypoxia are of clinical importance in anemia caused by acute autoimmune intravascular hemolysis. Thus, in the experimental group in animals with anemia caused by acute 
REVISTA DE LA UNIVERSIDAD DEL ZULIA. 3ª época. Año $12 \mathrm{~N}^{\circ} 32,2021$

Sergej V. Votrin et al. // Efficiency of the use of perfluorocarbon gas transport... 24-34

DOI: http://dx.doi.org/10.46925//rdluz.32.03

autoimmune intravascular hemolysis, which received donor erythrocyte mass as part of complex therapy, the level of hypoxia was significantly lower than in the control group. However, hyperbilirubinemia was noted as a result of increased autoimmune hemolysis, as a result of which the bilirubin level was significantly higher than in the control group and in the group with "Perftoran". The level of hypoxia in the group of animals with anemia, which received the drug "Perftoran" as part of the complex therapy, was significantly lower than in the control group, but at the same time the level of bilirubin was significantly lower than in the group with erythrocyte mass, which proves the absence of increased autoimmune hemolysis, which directly affects the mortality rate.

The mortality data show that correction of hypoxia in severe autoimmune hemolytic anemia is necessary, but for this it is necessary to use drugs that do not have immune aggression, as noted on donor blood preparations. The most effective way to eliminate hypoxia in severe autoimmune anemia caused by acute autoimmune intravascular hemolysis is the use of perfluorocarbon gas-transporting blood substitutes of the Perftoran type.

A comparative analysis of animal mortality was carried out between the two blocks of studies (Fig. 1). Studies have shown that the lowest mortality rate, from 9.9 to 13\%, both in cats and dogs in both blocks of studies, respectively, is observed when hypoxia is corrected with Perftoran for any type of anemia. However, the use of another gas transport hemocorrector - erythrocyte mass in the correction of hypoxia in the second block of studies caused by autoimmune intravascular hemolysis in dogs, showed that the lethality sharply increases to 53\% compared to animals where the red blood cell mass was used for posthemorrhagic anemia in the first block of studies $23,1 \%$ in cats. As noted, this is associated with hyperbilirubinemia as a result of increased autoimmune hemolysis.

Conclusion

The following conclusions can be drawn. Correction with the perfluorocarbon gas transport drug "Perftoran", carried out in animals with acute blood loss and acute autoimmune intravascular hemolysis to compensate for the hypoxic state, provides the necessary oxygen balance without increasing immune aggression, which ultimately does not lead to lethal iatrogenic complications. 
REVISTA DE LA UNIVERSIDAD DEL ZULIA. 3ª época. Año $12 \mathrm{~N}^{\circ} 32,2021$ Sergej V. Votrin et al. // Efficiency of the use of perfluorocarbon gas transport... 24-34 DOI: http://dx.doi.org/10.46925//rdluz.32.03

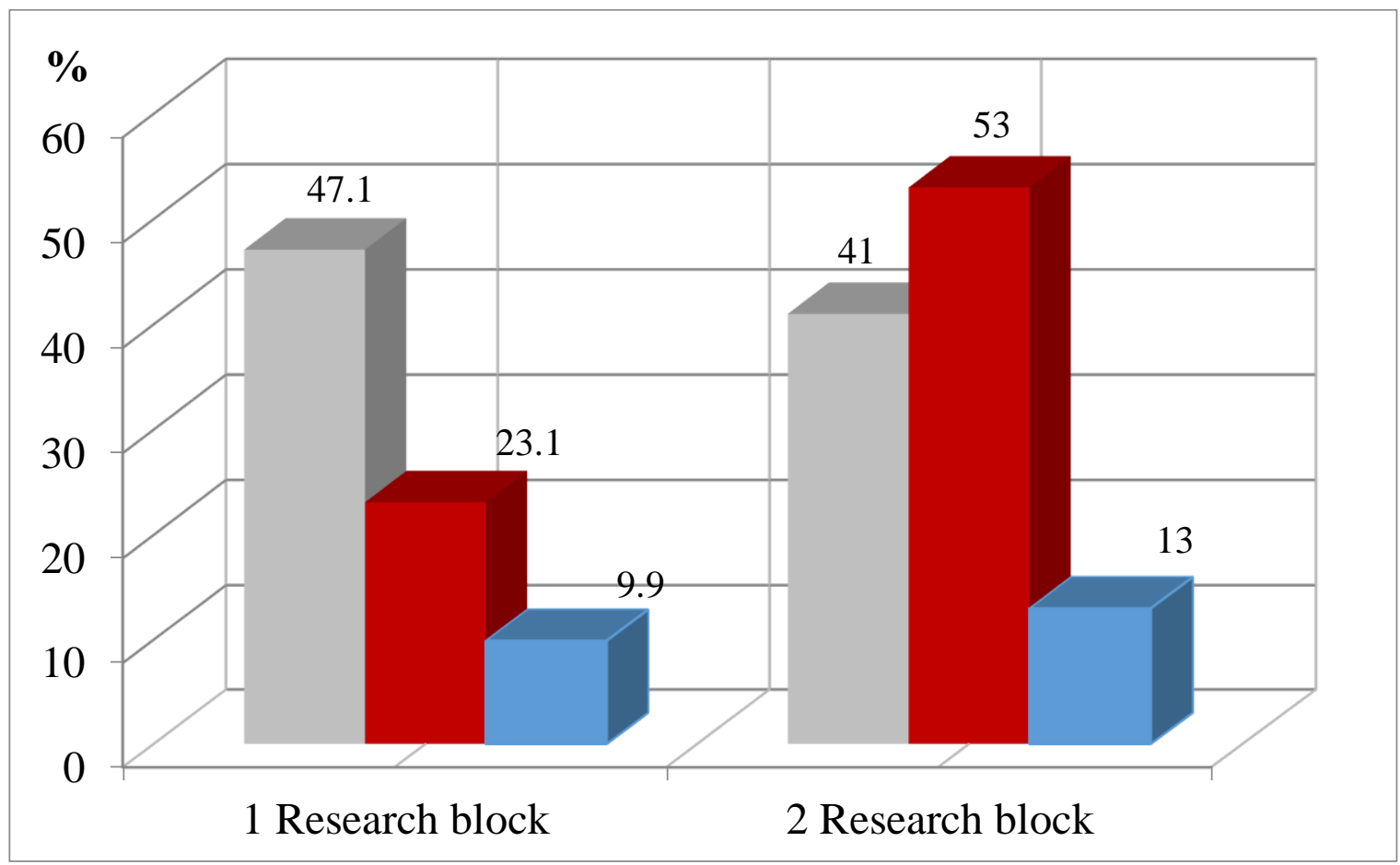

Figure 1. Comparative analysis of animal mortality between the two blocks of studies in the correction of hypoxia caused by posthemorrhagic anemia and autoimmune intravascular hemolysis. Control is gray. Erythrocyte mass is red. The drug "Perftoran" is blue color

Correction of hypoxia caused by acute autoimmune intravascular hemolysis with the help of erythrocyte mass enhances autoimmune hemolysis, thereby causing an increase in bilirubin and, as a consequence, a high mortality rate. The high clinical efficacy of the perfluorocarbon gas transport drug "Perftoran" for the correction of hypoxia caused by acute blood loss and acute autoimmune intravascular hemolysis is associated with its medicobiological and physicochemical properties: gas transport, rheological, anti-shock, antiischemic, anti-toxic, anti-ischemic.

The use of synthetic gas transport blood substitutes for the correction of various forms of hypoxia makes it possible to reduce the consumption of donor blood or even to refuse its use, which reduces the infection and the number of unwanted negative reactions in recipients. 
REVISTA DE LA UNIVERSIDAD DEL ZULIA. 3ª época. Año 12 Nº 32, 2021

Sergej V. Votrin et al. // Efficiency of the use of perfluorocarbon gas transport... 24-34

DOI: http://dx.doi.org/10.46925//rdluz.32.03

\section{References}

Alekseev, N. A. (2004). Anemia. Saint Petersburg: Hippokrat, 512.

Bialas, C., Moser, C. and Sims, C. A. (2019). Artificial oxygen carriers and red blood cell substitutes: A historic overview and recent developments toward military and clinical relevance. Trauma and Acute Care Surgery, 87 (1), 48-58. DOI: 10.1097/TA.0000000000002250

Nimand, H. G. and Suter, P. F. (2004). Diseases of dogs. A practical guide for veterinarians. Moscow: Aquarium Print, 816.

Plumb, D. K. (2002). Pharmacological preparations in veterinary medicine. Moscow: Aquarium LTD, 856.

Ragimov, A. A. (2015). Transfusiology: national guidelines. Moscow: GEOTAR-Media, 1184.

Shiffman, D. F. (2017). Pathophysiology of blood. Moscow: BINOM, 397.

Spiess, B. D. (2019). Military Supplement: Perfluorocarbon Emulsions, Platelet Counts and Inflammation. Journal Shock, 52 (1S), 13-18. DOI: 10.1097/SHK.0000000000001154

Vaden, Sh., Knoll, D. and Smith, F. (2013). Complete guide to laboratory and instrumental research in dogs and cats. Moscow: Aquarium Print, 1120.

Vorobiev, S. I., Votrin, S. V., Bolevich, S. B., Kutyshenko, V. P., Novikov, A. A., Kolotilova, M. L. and Orlova, A. A. (2016). Biological and physicochemical actions of a synthetic emulsion of a perfluorocarbon blood substitute. Non-traditional natural resources. Innovative technologies and products, 24, 220-229.

Vorobyev, S. I., Kutyshenko, V. P., Bolevich, S. B. and Votrin, S. V. (2020). Gas transport characteristics of hemocorrectors and perfusates based on perfluor-carbon blod-substituting emulsion. Serbian Journal of Experimental and Clinical Research, 21 (2), 147-155.

Votrin, S. V. and Vorobiev, S. I. (2017). The use of perfluorocarbon blood substitute in the treatment of acute posthemorrhagic anemia in cats. Russian veterinary journal, 8, 16-21.

Votrin, S. V., Bolevich, S. B., Vorobiev, S. I., Orlova, A. S., Bolevich, S. S., Tachieva, B. I. and Korsakov, D. Yu. (2018). Elimination of hypoxia in acute autoimmune intravascular hemolysis of erythrocytes using perfluorocarbon blood-substituting emulsion in experiment. Sechenovskii Bulletin, 2(32), 5-14. 